\title{
Utilization of Augmented Reality in Automotive Subjects for Basic Competencies of Four- Wheeled Vehicle Brake Systems
}

\author{
M. Farkhan \\ Information Engineering \\ University of Maarif Hasyim Latif \\ Sidoarjo, Indonesia \\ farkhan@dosen.umaha.ac.id \\ Francisca Haryanti Chandra \\ Information Technology \\ ISTTS \\ Surabaya, Indonesia \\ fhc@stts.edu
}

\author{
Endang Setyati \\ Information Technology \\ ISTTS \\ Surabaya, Indonesia \\ endang@stts.edu
}

\begin{abstract}
In automotive learning, teachers generally use books and teaching aids as learning media. Automotive learning outcomes show the low value of learning outcomes. Thus a learning media

students were more active in learning activities and students were eager to take part in learning. This proves that students are interested in this media which can generate motivation to learn.
\end{abstract} is needed that can help improve learning outcomes. One way to overcome this problem is to use learning media that utilize augmented reality technology. In this study, a learning media using augmented reality technology based on android was developed to simulate the brake system on four-wheeled vehicles in 3 dimensions. The Augmented Reality work system used is marker based tracking, and uses 3D Max software and the Vuforia plug-in. In terms of pedagogy, this learning system uses the Modality Principle.

Participants are class XI students of SMK YPM 4 Taman. This research uses experimental research. The students involved were 44 students divided into 2 groups, with each group consisting of 22 students. Both groups received a pre-test and a post-test. The experimental group was given treatment with Augmented Reality-based learning media, while the control group did not use conventional learning media. After making comparisons, the results show less than optimal due to the pandemic period.

The results showed that the pre-test result between the control group and the experimental group was 49.32, and the post-test result for the control group was 62.73, while for the experimental group it was 73.18. So that from the difference in the difference in post-test scores between the experimental group and the control group shows that the treatment factor by providing Augmented Reality-based learning media in the experimental group has an influence. From observations and interviews,
Keywords: Augmented Reality, Automotive Brake System, Learning Media.

\section{INTRODUCTION}

Vocational education is education that prioritizes the mastery of skills for graduates. Not only skills, but also knowledge to support these skills. Students must learn in order to get the knowledge in question. One of the skills in vocational education is light vehicle technology. Light vehicle technology graduates are required to master knowledge and skills in the field of light vehicle technology. One of the basic competencies found in light vehicle technology expertise is about brake systems, where students are expected to be able to identify and understand the mechanisms of the brake system itself.

For fun and interactive learning purposes, adequate learning media is needed. With adequate learning media it will help students' imagination in recognizing real objects Through the $3 \mathrm{D}$ object making software, components for the brake system itself are compiled, resulting in a 3dimensional form of the brake system working mechanism which will be utilized by students in learning.

The components of the brake system are arranged in such a way through Augmented Reality (AR) technology so that they become interactive information that can facilitate the intended learning. AR is a concept that combines the virtual world with the real world to produce information from data taken from a system on the designated real object so that the boundary between the two becomes thinner. AR can create interactions between the virtual world and the real world, all information can be added so that the and systems before students carry out practicum activities. 
BEST

Journal of Applied Electrical \& Science Technology - University of PGRI Adi Buana Surabaya

p-ISSN 2715-2871

e-ISSN 2714-5247

information is displayed in real-time as if the information becomes interactive and real.

To see how much influence with learning using this augmented reality, a division of groups is carried out where each group will receive a pre-test and post-test. The difference is that one particular group uses conventional learning (without augmented reality) and another group uses augmented reality.

According to Faieza Abdul Aziz [1] that the ARbased application developed has great potential in automotive maintenance training. And the results show the effectiveness of applications developed for training purposes.

\section{USING AUGMENTED REALITY AS LEARNING MEDIA}

Augmented Reality is a technology that combines two-dimensional and / or three-dimensional virtual objects into a real three-dimensional environment and then projects these virtual objects in real time [4].

The way AR works is divided into two types based on the method, namely:

a. Augmented Reality Marker

Marker is usually a black and white illustration of a square with a bold black border and white background. The computer will recognize the position and orientation of the marker and create a $3 \mathrm{D}$ virtual world, namely the point $(0,0,0)$ and 3 axes namely, $\mathrm{X}, \mathrm{Y}$ and $\mathrm{Z}$.

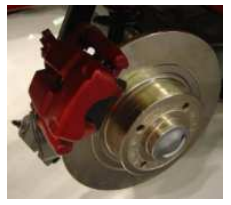

Figure 1. Disc Brake

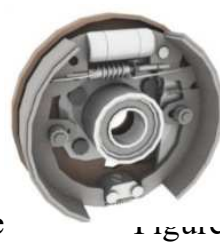

2. Drum Brake
Unlike face tracking, which only recognizes human faces in general, 3D object tracking techniques can recognize all forms of objects that are around

- Motion Tracking

This technique captures motion, widely used in film productions that attempt to simulate motion.

- GPS Based Tracking

This technique takes data from the GPS device and the compass and displays it in the desired direction.

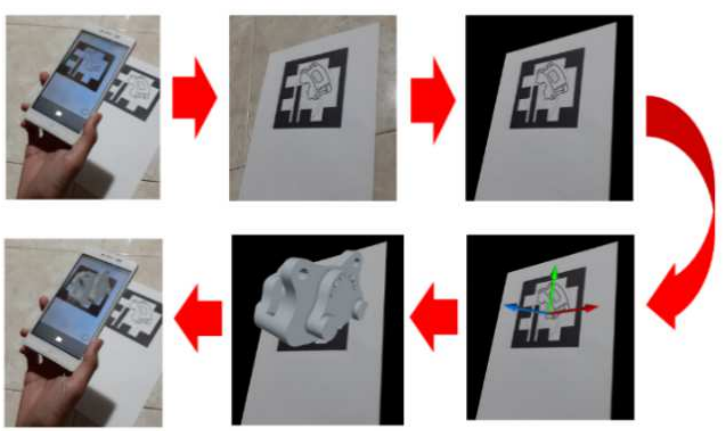

Figure 4. Augmented Reality

\section{INTERFACE DESIGN}

In developing this application there is an interface design, it can be seen in the pictures below.

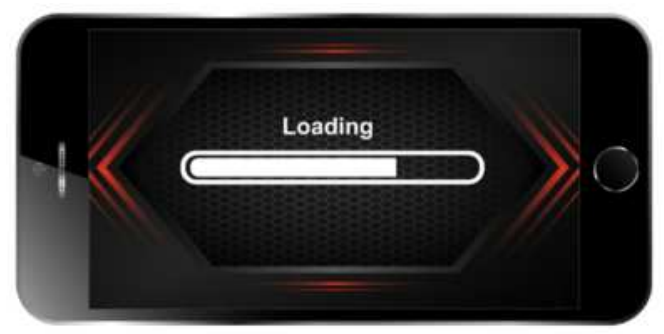

Figure 5. Splashscreen

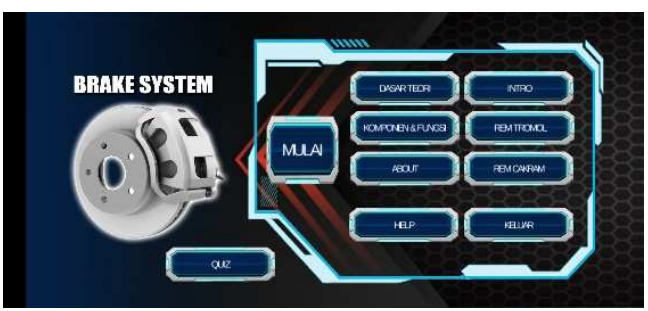

Figure 6. Main Menu

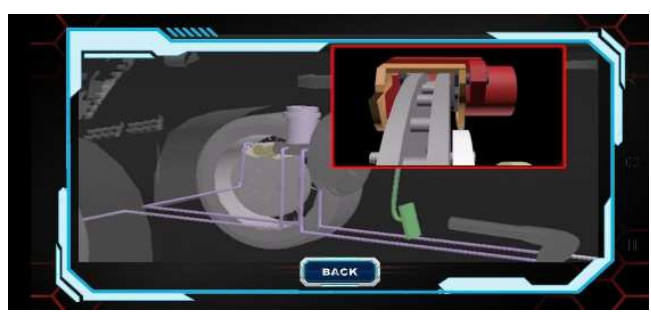

Figure 7. Intro Menu

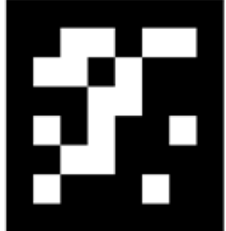

Figure 3. Marker

Markerless Augmented Reality

In this method, markers are not used to display digital elements. The development of markerless augmented reality can be markerless tracking, such as:

\section{- Face Tracking}

Face tracking is markerless AR that uses an algorithm developed so that computers can recognize human faces in general by recognizing the position of the eyes, nose and mouth. And ignore other objects around it.

SD Object Tracking 


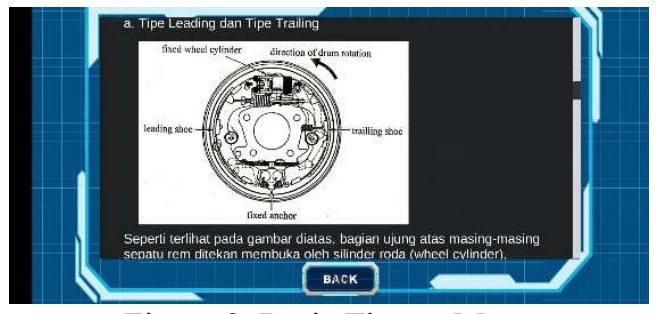

Figure 8. Basic Theory Menu

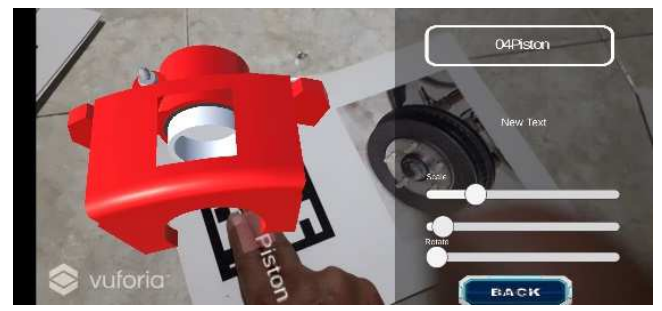

Figure 9. AR Menu

\section{RESULTS AND DISCUSSION}

The testing process with pre-test and post-test was carried out to determine the level of difference before and after learning. The types of questions that will be given in the Pre-Test and Post Test are in the form of questions with cognitive, affective and psychomotor aspects. Meanwhile, to determine the level of usefulness of the system used a questionnaire based on the ISO 25010 standard on aspects of the Usability Test (Usability).

Table 1

Investigating Factor

\begin{tabular}{|c|c|c|c|}
\hline Variable & Factor & $\begin{array}{c}\text { Item } \\
\text { Number }\end{array}$ & $\begin{array}{c}\text { Number } \\
\text { of } \\
\text { Question }\end{array}$ \\
\hline \multirow{4}{*}{$\begin{array}{l}\text { The level of } \\
\text { understanding } \\
\text { of class XI } \\
\text { students of } \\
\text { Light Vehicle } \\
\text { Engineering } \\
\text { towards } \\
\text { learning with } \\
\text { brake system } \\
\text { material }\end{array}$} & Definition & 10,18 & 2 \\
\hline & Type & $\begin{array}{c}4,6,14 \\
16\end{array}$ & 4 \\
\hline & Component & $\begin{array}{c}2,3,5,11 \\
15\end{array}$ & 5 \\
\hline & Mechanism & $\begin{array}{c}1,7,8,9 \\
17,12,13, \\
19,20\end{array}$ & 9 \\
\hline & & & 20 \\
\hline
\end{tabular}

The number of questions used to determine the level of understanding of students was 20 items with 5 (five) indicators of how the drum brake worked, 5 (five) drum brake components and disc brake components, 4 types of drum brakes and disc brakes. (four) items, 2 (two) false air exhausts, 2 (two) item brake shoe clearance adjustments, 2 (two) items on the strengths and weaknesses of drum brakes and disc brakes.
The mean value obtained from the pre-test results was for group A was 61.25 and for group B was 56.68. While the average score obtained from the post-test results for group A was 70.63 and group B was 79.50.

The increase in learning outcomes between group A and group B was $15.31 \%$ and $39.78 \%$.

Table 2

Results of the Validity Test of Student Understanding

\begin{tabular}{|c|c|c|c|c|c|c|c|}
\hline & Question & $\begin{array}{l}2] \mathrm{r} \\
\text { table }\end{array}$ & & ] count & & 4] Ir & nation \\
\hline$[5$ & Question 1 & 0,628 & & [7] 0,3 & & & \\
\hline$[9$ & Question 2 & 0,427 & !] & & 0,3 & 2] & Valid \\
\hline 3] & Question 3 & 0,643 & j] & & 0,3 & 6] & Valid \\
\hline 7] & Question 4 & | 0,734 & )] & & 0,3 & 0] & Valid \\
\hline 1] & Question 5 & ] 0,394 & 3] & & 0,3 & 4] & Valid \\
\hline 5] & Question 6 & | 0,457 & 7] & & 0,3 & 8] & Valid \\
\hline 9] & Question 7 & 0,581 & l] & & 0,3 & 2] & Valid \\
\hline 3] & Question 8 & 0,310 & j] & & 0,3 & 6] & Valid \\
\hline 7] & Question 9 & ] 0,322 & )] & & 0,3 & 0] & Valid \\
\hline 1] & $\begin{array}{l}\text { Question } \\
10\end{array}$ & $\begin{array}{l}\mid 2]- \\
0,119\end{array}$ & 3] & & 0,3 & 1] & Invalid \\
\hline 5$]$ & $\begin{array}{l}\text { Question } \\
11\end{array}$ & 0,415 & 7] & & 0,3 & 8] & Valid \\
\hline เ9] & $\begin{array}{l}\text { Question } \\
12\end{array}$ & 0,457 & !] & & 0,3 & 2] & Valid \\
\hline ;3] & $\begin{array}{l}\text { Question } \\
13\end{array}$ & 0,652 & ;] & & 0,3 & 6] & Valid \\
\hline ;7] & $\begin{array}{l}\text { Question } \\
14\end{array}$ & $\begin{array}{l}j 8]- \\
0,087\end{array}$ & )] & & 0,3 & )] & Invalid \\
\hline 1] & $\begin{array}{l}\text { Question } \\
15\end{array}$ & $\begin{array}{l}52]- \\
0,032\end{array}$ & 3] & & 0,3 & t] & Invalid \\
\hline 5] & $\begin{array}{l}\text { Question } \\
16\end{array}$ & ] 0,479 & 7] & & 0,3 & 8] & Valid \\
\hline [9] & $\begin{array}{l}\text { Question } \\
17\end{array}$ & 0,365 & l] & & 0,3 & 2] & Valid \\
\hline 73] & $\begin{array}{l}\text { Question } \\
18\end{array}$ & $\begin{array}{l}74]- \\
0,064\end{array}$ & j] & & 0,3 & 5] & Invalid \\
\hline 77] & $\begin{array}{l}\text { Question } \\
19\end{array}$ & ] 0,573 & )] & & 0,3 & 0] & Valid \\
\hline 1$]$ & $\begin{array}{l}\text { Question } \\
20\end{array}$ & ] 0,417 & 3 & & 0,3 & 4] & Valid \\
\hline
\end{tabular}




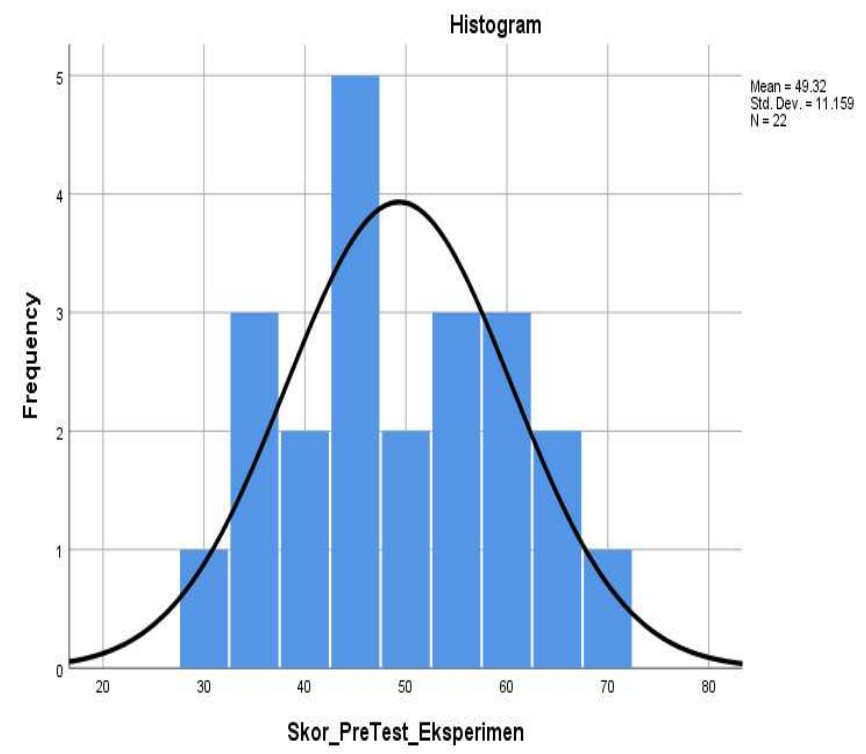

Figure 10. Experiment Class PreTest Score

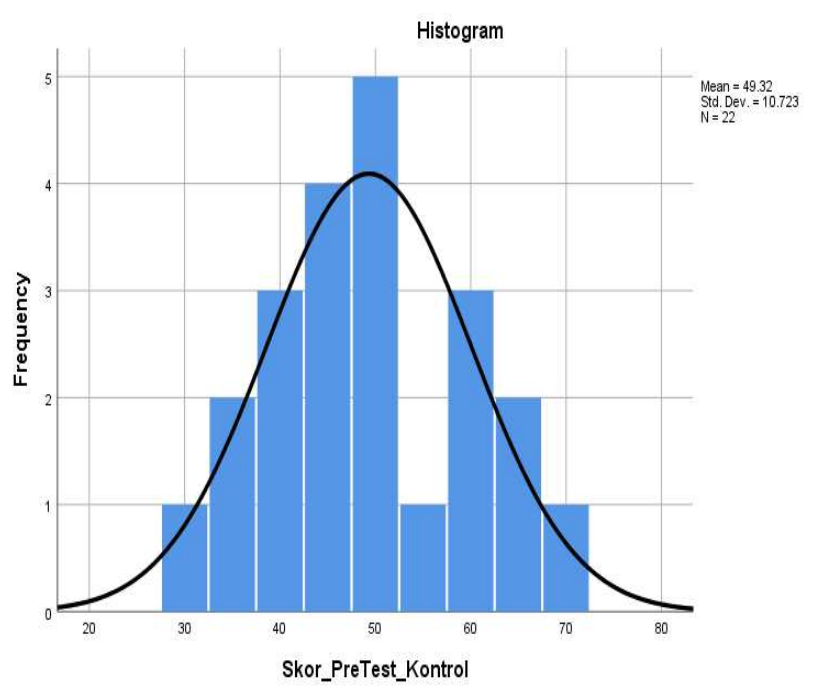

Figure 11. Control Class PreTest Score

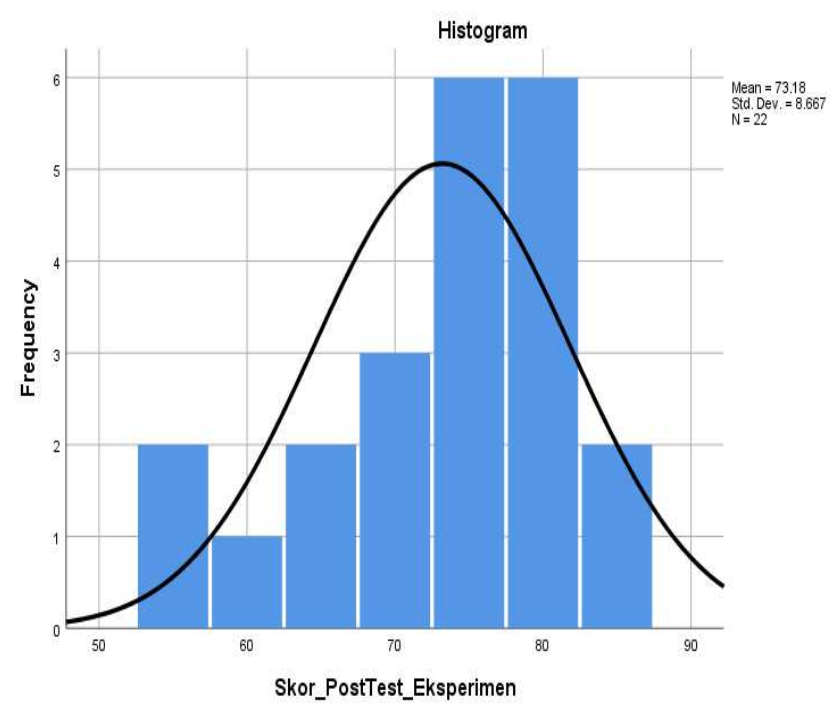

Figure 10. Experiment Class PostTest Score

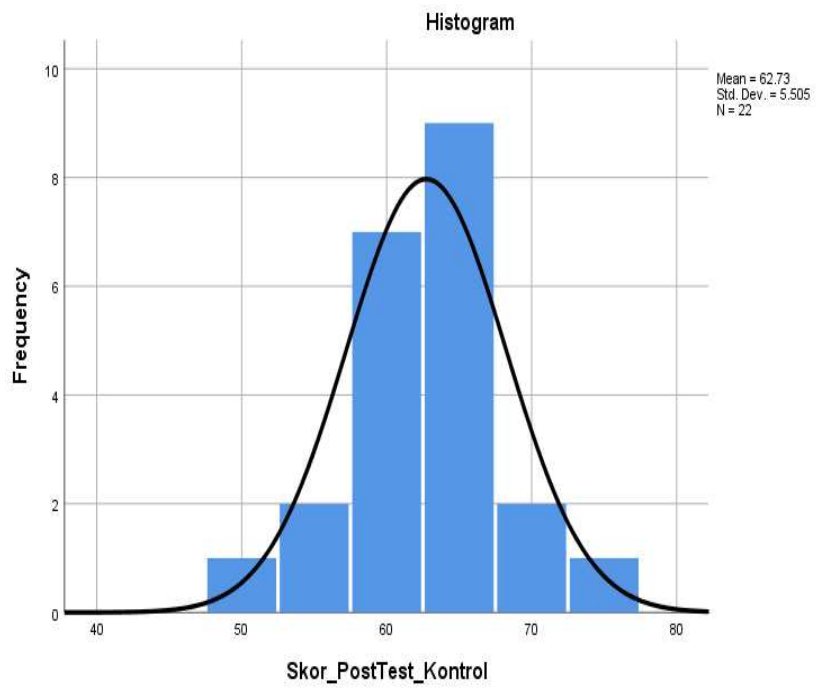

Figure 11. Control Class PostTest Score

\section{CONCLUSION}

The program trial during the Covid19 pandemic was carried out in several stages, the first stage was an experiment by class XI students at SMK YPM 4 Taman which was carried out at their respective homes, so that neither classroom teachers nor researches could directly observe and supervise participants students do the experiment. The second stage is an experiment conducted by the classroom teacher, and the result of the experiment concluded that the augmented reality-based application that was built could help students.

The test result using the latest smartphone, even with low lighting, the marker can be tracked quickly. And when using an older generation smartphone or using a tablet with low lighting, it will result difficult marker tracking process (tends to take a long time).

\section{REFERENCE}

[1] Faieza Abdul Aziz, Faid Abdullah, Lai Lai Win (2018). "Using Marker Based Augmented Reality for Training in Automotive Industry".

[2] Antonio Mireles Medina, Francisco Javier Carrilo, Jose Angel Montes Olguin, (2018). "Planning and Allocation of Digital Learning Objects with Augmented Reality to Higher Education Students According to the VARK Model".

[3] R. T. Azuma, "A Survey of Augmented Reality Navigation" Presence Teleoperators Virtual Environ., vol. 6, no. 4, pp. 355-385, 1997.

[4] L. A. C, Authoring Interactive Multimedia. Massachusettes: Academic Press, Inc, 1994.

[5] A. Lund and B.A.M. Lund, "Measuring Usability with the USE Questionnaire”, March. 2016.

[6] Yunbo Zhang, Tsz-Ho Kwok, "Design and Interaction Interface Using Augmented Reality for Smart Manufacturing”, Procedia Manufacturing, 2018 
Journal of Applied Electrical \& Science Technology - University of PGRI Adi Buana Surabaya

p-ISSN 2715-2871

e-ISSN 2714-5247

[7] Faieza Abdul Aziz, Eisa Alostad etc, "Augmented Reality Marker Based to Aid Inspection and Maintenance Process in Automotive Industry", International Journal of Engineering and Advanced Technology (IJEAT), 2019.

[8] V. Geroimenko, "Augmented Reality Technology and Art: The Analysis and Visualization of Evolving Conceptual Models", 2012, pp. 445-4 
BEST

Journal of Applied Electrical \& Science Technology - University of PGRI Adi Buana Surabaya

p-ISSN 2715-2871

e-ISSN 2714-5247

46 | BEST, Vol. 03, No. 02, 2021 